\title{
What is “Chinese Modern Calligraphy”? An Exploration of the Critical Debate on Modern Calligraphy in Contemporary China
}

\begin{abstract}
Adriana Iezzi
“Sapienza” University of Rome, Rome, Italy

Since the mid-1980s Chinese calligraphy art has undergone a radical change and has opened itself to experimentation. Nowadays in China this artistic revolution has sparked a vivid debate among the art critics on three main topics: (1) definition of the phenomenon; (2) analysis of its nature; and (3) classification of the artistic production. In this article, all these aspects are analysed in order to give a comprehensive view of the present theoretical discussion and of its future development.

Keywords: Chinese Modern Calligraphy (CMC), contemporary China, art critic, critical debate, modernity, contemporary art, modern art
\end{abstract}

\section{Introduction}

Since the mid-1980s Chinese calligraphy art has undergone a radical change and has opened itself to experimentation. Calligraphy has gradually lost its connection with Chinese language and has gradually strayed from the concept of traditional aesthetics which consists of strict rules and stylistic standards that have never changed over centuries. From the end of the 1990s, in China this artistic revolution has sparked a vivid debate on "Modern Calligraphy" among the art critics. In order to give an overview of the different critical positions emerged until now, to systematize this fragmented and complex matter, and to define a periodization of the evolution of the theoretical discussion, it is fundamental to distinguish the main debate topics, and to analyze each of them in the details. Three are the main topics of the critical debate on "modern calligraphy" in China nowadays: (1) definition of the phenomenon; (2) analysis of its nature; and (3) classification of the artistic production.

\section{The Definition of the Phenomenon}

As to the first point, it is known that the expression commonly used by Chinese scholars to describe the transformation process of contemporary calligraphy is Zhōng guó xiàn dài shü fă 中国现代书法 (“Chinese modern calligraphy"-CMC). This formula was first used in the "First Exhibition of Chinese Modern Calligraphy”(Zhōng guó xiàn dài shū fă shǒu zhăn 中国现代书法首展), held in October 1985 at the National

Adriana Iezzi, Ph.D., Department of Oriental Studies, Sapienza University of Rome. 
Art Museum of China in Beijing. ${ }^{1}$ But, what do we mean exactly when we say "Chinese Modern Calligraphy”? This expression consists of three different words: Zhōng guó, xiàn dài, and shū fă. In order to understand their exact meaning in the context we are referring to, we need to analyze each of the words separately.

As to the first word, Zhōng guó ("China”), the problem is: Do we want to refer only to People’s Republic of China (P.R.C.) or also to Taiwan? Has Hong Kong to be considered or not? What about the overseas Chinese (hăi wài de Huá rén 海外的华人) artistic production? QU (2008) explains that the word Zhōng guó is used only to distinguish “Chinese Modern Calligraphy” from “Japanese Modern Calligraphy” (Rì běn xiàn dài shū fă 日本现代书法). He says that even if Chinese modern calligraphy was influenced by the Japanese one, the differences between them are evident in many fundamental aspects, so what is important is to underline the "Chinese" features of the new calligraphic forms. When QU Li-feng uses the term Zhōng guó, he wants to refer to the concept of Zhōng guó xìng 中国性 “Chineseness, Chinese nature”. When he analyzes the modern calligraphic production, his focus is on the selection of the artworks which clearly present Chinese characteristics, and it is not important if the artists come from P.R.C., Hong Kong, Taiwan or foreign countries. QU Li-feng's point of view is the most popular among the Chinese art critics, ${ }^{2}$ whose way of thinking is extremely influenced by the Chinese concept of hé hé wén huà 和合文化 "harmonious and integrated culture":3 Their attempt is to minimize the geographical differences and to bring everything back to the typicality and specificity of the Chinese culture. In recent years, a few attempts to analyze separately the artistic production of specific cultural areas have emerged, for example, for Taiwan (HUANG, 2011) and Hong Kong (XU, 2010), but when the Chinese scholars refer to Zhōng guó these areas are automatically included. The focus is always on “continental China” (Zhōng gúo dà lù 中国大陆) and on P.R.C. artists, and the other areas are marginalized and never distinguished. Actually, the problem is not the inclusive approach, but the negation of the presence of specific characteristics from the artists from Taiwan, Hong Kong, and overseas, because they belong to cultural background different from the "Chinese" one. ${ }^{4}$

Then, when we use the word xiàn dài, do we refer to a temporal indicator or to a cultural one? $?^{5}$ If we consider xiàn dài as a temporal indicator, we should immediately think of the starting date of "modern age" in China, which is the fourth May 1919, but, as to CMC, none of the Chinese art critics refer to this date:

\footnotetext{
${ }^{1}$ For a more detailed description of the artworks displayed in the exhibion, see the exhibition catalogue: WANG Xue-zhong (1986), XIANDAI SHUFA-Xiandai shuhua xuehui shufa shoujie zuopin xuan 现代书法一现代书画学会书法首届作品选, Beijing: Beijing Sport University Press. For a detailed reconstruction of the exhibition planning process and of the different phases of the exhibition, see PU Lie-ping \& GUO Yan-ping (2005), Zhongguo xiandai shufa dao hanzi yishu jianshi 中国现代书 法到汉字艺术简史, Chengdu: Sichuan Fine Arts Press, pp. 19-24. This exhibition represented the birth of the whole movement of the so-called "Chinese modern calligraphy".

2 The only exception seems to be the approach by YANG Ying-shi (YANG, 2004), because at the beginning of his article he distinguishes the homeland of each artist. But this is only an apparent exception, because when he then classifies their artistic production, he forgets this distinction and conforms his approach to the others.

${ }^{3}$ For further information about this concept, see CHEN (2010), “'Harmonious and Integrated Culture' and the Building and Communication of China’s National Image” (pp. 148-154).

4 Just to give two examples of this approach, see ZHANG Ai-guo (ZHANG, 2007) and LIU Can-ming (LIU, 2010). In their works, both of these scholars give a clear definition of the terms xiàn dài and shü fă, but they don't mention the term Zhōng guó. In the classification of the artistic production, they name artists from Taiwan, Hong Kong, and overseas, but they are marginalized and they neither distinguish them from the other artists from P.R.C. nor highlight their specific cultural features.

${ }^{5}$ To understand the complexity of this question, just think that Chinese scholars organized a whole conference to debate this only question. For more details, see QIU Zhen-zhong (2004), Yuanzi shufa一Dui yilei yishu de mingming yu qita 源自书法一对一类 艺术的命名与其他 (p. 276).
} 
Someone considers the year 1881 (CHEN, 1996), someone else the year 1949 (LI \& LIU, 2009; LU, 2004), and most of them indicate the year 1985 (PU \& GUO, 2005; LIU, 2010; YANG, 2009; FU, 1998; ZHANG, 1998; SHEN, 2001; CHEN, 2005). Why these different dates? Maybe, it is because xiàn dài is not used as a temporal indicator but as a cultural one, as ZHU Qing-sheng (ZHU, 2000, 2004) and ZHANG Ai-guo (ZHANG, 2007) point out. In particular, ZHU Qing-sheng focuses on the difference between the terms xiàn dài yì shù 现代艺 术 “modern art” and dāng dài yì shù 当代艺术 “contemporary art” to explain the exact meaning of the word xiàn dài in the expression Zhōng guó xiàn dài shū fă. He argues that:

As to art, the "modern stage" (xiàn dài yì shù jiē duàn) [...] begins when revolutionary ideas emerge, new concepts appear, and artworks completely different from classical (or traditional) ones come to light. When we use the expression dāng dài yì shù 当代艺术 (contemporary art) [...] we can also refer to classical forms and concepts shaped in the present times, while when we refer to xiàn dài yì shù 现代艺术 “modern art” this can never happen. (p. 159)

According to ZHU Qing-sheng, the term xiàn dài means "something opposite to tradition”: It is a cultural indicator of something that is changing in contemporary China. Most of Chinese art critics agree with ZHU Qing-sheng's point of view (GAN, 1992; FU, 2001; SHENG, 2004; LIU, 2010), and among them, LIU Can-ming (2010) best sums up this concept:

The word xiàn dài means both "modern times” and "modern culture”. The expression "modern calligraphy” (xiàn dài $s h \bar{u} f \breve{a}$ ) contains two fundamental connotations: one is temporal, the other is cultural. (p. 4)

But if xiàn dài shū fă rejects traditional forms, can it be still considered "calligraphy”?

Regarding to "calligraphy", to the term $s h \bar{u} f a ̆$, the problem is: Is it possible to identify some of the so-called "modern calligraphy" artworks, for example, those in Figure 1 and 2, as "calligraphy”? The main question is that while traditional calligraphy has always been at the same time a "verbal art" as well as an “abstract art” (ZHANG, 1998), the “art of writing characters” (xiě zì yì shì 写字艺术) as well as the “art of writing lines” (xiàn tiáo yì shù 线条艺术) (LIU, 2010), in recent years, instead, calligraphy has split into two parts and sometimes has become a "verbal art" or an "abstract art", the "art of writing (meaningful/un-meaningful) characters” (see Figure 1) or the "art of writing (abstract/painting-like) lines” (see Figure 2).

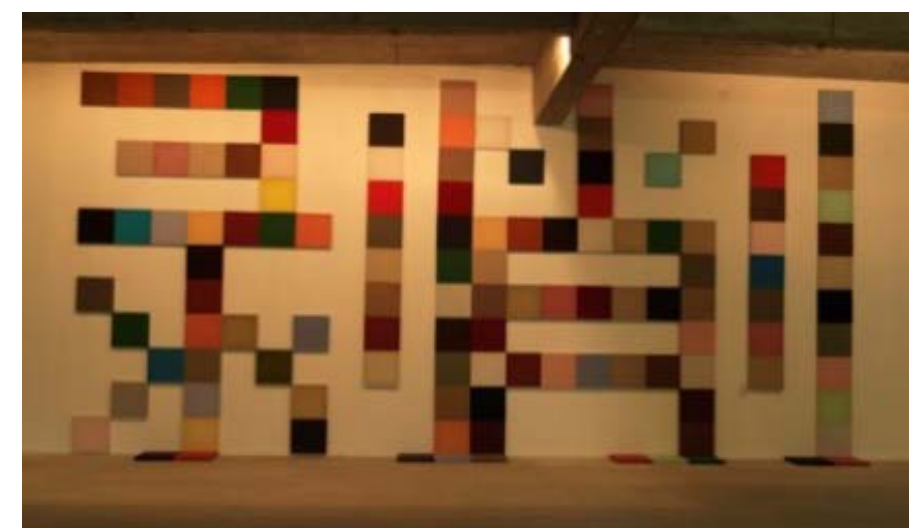

Figure 1. WU Shan-zhuan, Color into exploitation 色彩进入剥削, 2009, installation, Shanghai Songjiang Creative Studio, 2009.09.10-2009.09.14. Reproduced in: WANG Dong-ling (2011, p. V). 


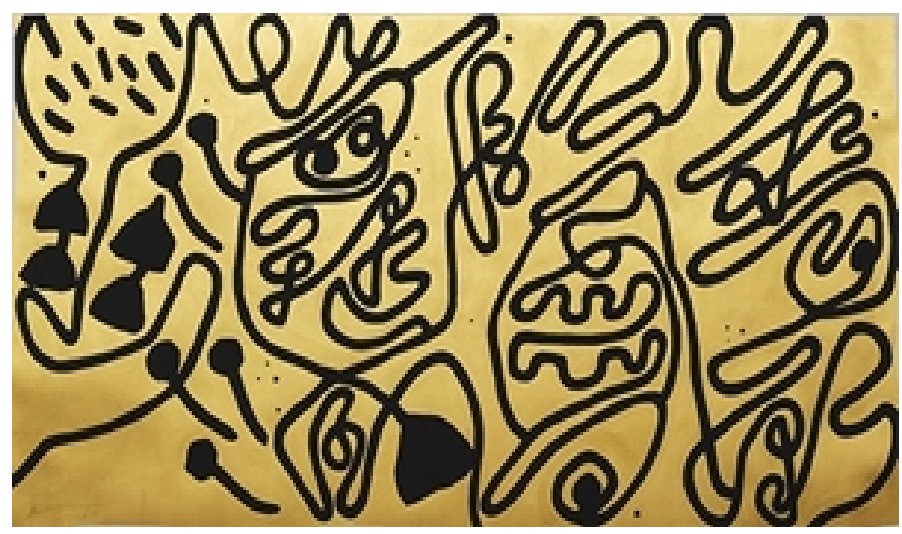

Figure 2. WEI Li-gang, QiangWei Yuan Dong Luo Dao Chui (The rosebush crawls around the entrance to the courtyard with a few vines dropping down), 2011, ink and acrylic on paper, $243 \times 123 \mathrm{~cm}$, Goedhuis Contemporary Gallery. Source: Goedhuis Contemporary Gallery website.

As the result of this analysis, we can affirm that the definition of $s h \bar{u} f \breve{a}$ and the whole expression "Chinese Modern Calligraphy” are both inadequate and requires a deep revision.

Some Chinese scholars have tried to propose alternative definitions. Among them, the most important are:

(1) “calligraphism” (shü fă zhǔ yì 书法主义, LUO, 1993);

(2) “flexiblecalligraphy” (jī dòng shū fă 机动书法, ZHANG, 1993);

(3) “anti-calligraphy” (făn shū fă 反书法/fêi shu fă 非书法/wú zì shü fă 无字书法/fềi Hàn zì 非汉字/fếi Hàn zì shü fă 非汉字书法, WANG,1994; ZHANG, 1999; ZHU, 2000; QIAN, 2002);

(4) “modern calligraphic experimentation” (xiàn dài shū fă shì yăn 现代书法试验, ZHU, 2000);

(5) “modern art of calligraphic nature” (shū fă xìng xiàn dài yì shù 书法性现代艺术, HONG, 2001);

(6) “calligraphic art” (shī yì 书艺, CHEW, 2001);

(7) “modern structuralist calligraphy” (xiàn dài jiě gòu zhǔ yì shū fă 现代结构主义书法, QIAN, 2002);

(8) “art from calligraphy” (yuán zì shū fă yì shù 源自书法艺术, QIU, 2004);

(9) “avant-garde calligraphy” (xiān fēng shū fă 先锋书法, MA, 2004; qián wèi shū fă 前卫书法, LIU, 2008);

(10) “post-modern calligraphy” (hòu xiàn dài shü fă 后现代书法, ZHU, 2004);

(11) “art of Chinese characters” (Hàn zì yì shù 汉字艺术, PU, 2005);

(12) “modern calligraphic appearance” (xiàn dài shū xiàng 现代书象, FU, 2011).

A detailed analysis of each of these definitions unfortunately shows that none of them properly defines the whole phenomenon of the so-called CMC. As a consequence for this, we can affirm that it is impossible to give a unitary label to an unstable, constantly changing and multi-faceted phenomenon as the one we are referring to. This is why I think it is necessary to overturn the standard definition passing from the definition "Chinese modern calligraphy" (Zhōng guó xiàn dài shū fă) to the definition "modernity of Chinese calligraphy" (in Chinese something similar to Zhōng guó shū fă de xiàn dài xìng 中国书法的现代性), obviously as regard to a contemporary context. Why this? Because it is "modernity" that allows the art of calligraphy to be so productive and changeable in contemporary times. The solution to the question is to identify and recognize how this modernity is interpreted in contemporary Chinese artworks, in order to illustrate the evolution of this ancient art in all of its forms. 


\section{The Analysis of the Nature of the So-called “Chinese Modern Calligraphy”}

The second question is about the nature of the so-called "Chinese modern calligraphy" and the relation between modernity and tradition. The burning question for the art critics is: "Is the so-called CMC still calligraphy or not?”

As to this question, two are the main positions: (1) Professor WANG Dong-ling sustains that CMC is still calligraphy (WANG, 2005, 2011); (2) Professor WANG Nan-ming sustains that is not calligraphy yet (WANG, 1994, 2005). Even if these two positions seem to be alternative, both of them are valid and refer to two different approaches to the question: The first one refers to the modernists' perspective, the second one to the avant-garde's. When we speak of Chinese calligraphy, the phenomenon of modernity is like a Janus with two faces, the first one (the modernists') is still looking to the past and the second one (the avant-garde's) is looking to the future. ${ }^{6}$

\section{Classification of the Artistic Production}

The third question debated by the scholars focuses on the artistic production of the so-called CMC. The author has selected 24 different hypothesis of classification, 21 suggested by Chinese art critics (LI, 1991; ZHANG, 1998; FU, 1998; TAO, 1998; FU, 2000, 2004; SHEN, 2001; LUO, 1996, 2001; HONG, 2001; YANG, 2001, 2009; LANG, 2003; QIU, 2004; GAO, 2004; CHEN, 2005; LIU, 2006, 2008; CHENG, 2006; ZHANG, 2007; LIU, 2009; ZHU, 2009; HONG, 2010; WANG, 2010) and only three by non-Chinese scholars (CHEW, 2001; BARRASS, 2002; WEAR, 2008) (See Figure 3). In the table below, these hypotheses have been grouped into two categories, the first one written in Chinese language and the second one in Western language. As you can notice, almost only Chinese academic circles are involved in this debate.

If we look at Chinese references, we can argue that three are the pivotal points for the development of the discussion about the artistic production of the so-called CMC: 1998, 2001, and 2007. Starting from these three moments, it is possible to suggest a periodization of this critical debate in four stages (see Figure 4):

(1) The first one goes from the beginning of the 1990s to 1998. During this period, the first attempts to classify the artistic production of the so-called CMC are arisen. These classifications focus only on few aspects, have no scientific approach (there are no examples of artists and artworks), and use only two keywords to distinguish currents: hui huà "painting” (e.g., LI Xian-ting, 1991, who divides the modernist production into two mainstreams according to the different way in which calligraphy and painting interact in the artworks), or Hàn zì "Chinese characters" (e.g., LUO Qi, 1996, who divides the phenomenon of "calligraphism” in three different parts on the base of the manipulation of Chinese characters).

(2) The second stage goes from 1998 to 2000. In 1998, the first complete classification of the CMC is proposed by FU Qing-sheng, who divided the artistic production into five typologies (see Figure 5): (1) writing poems using Chinese characters; (2) freehand brushwork for no-characters works; (3) Fluid and passionate ink works; (4) conceptual works; and (5) calligraphic performance and installations. This classification perfectly reflects the situation of CMC at the end of the 1990s, even if it doesn't consider the avant-garde movement which spread out abroad at the end of the 1980s.

\footnotetext{
${ }^{6}$ For a detailed analysis of the two perspectives, see Iezzi, A. (2013), “Contemporary Chinese Calligraphy between tradition and innovation” (pp. 163-165, 167-168).
} 


\section{CHINESE LANGUAGE}

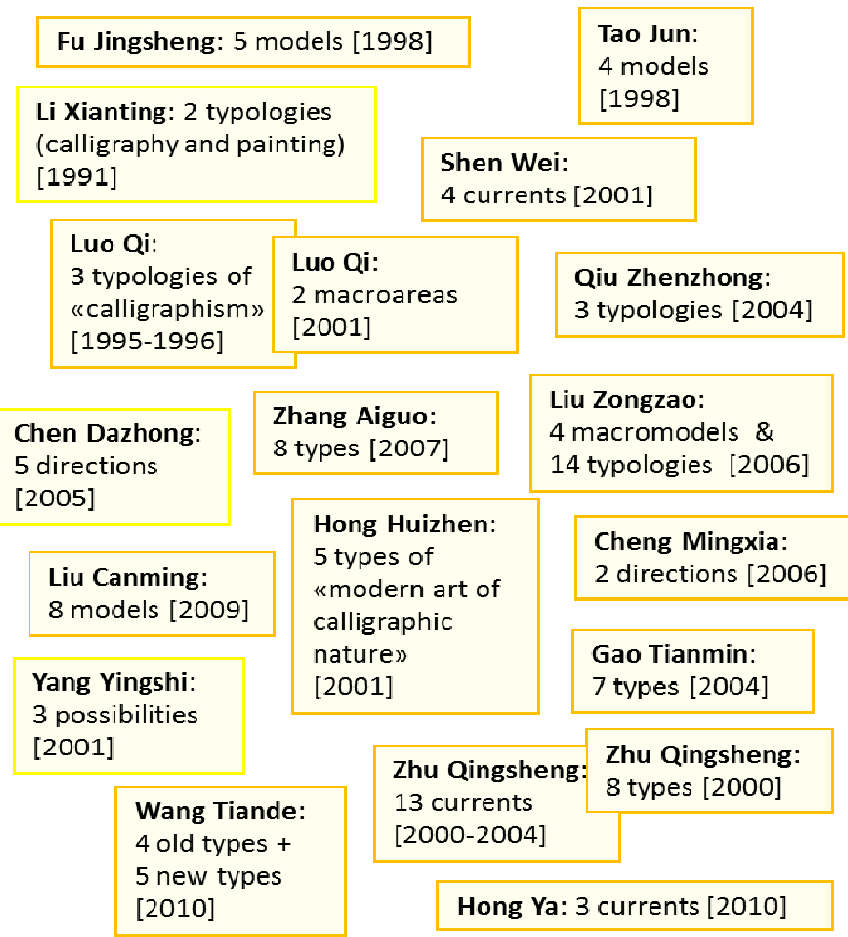

\section{WESTERN LANGUAGE}

\begin{tabular}{|l|}
\hline Zhang Yiguo: \\
2 macroareas \\
(paintinglike \\
calligraphy and non \\
character calligraphy) \\
[1998]
\end{tabular}

\section{Chew Kim Liong:}

3 typologies

(personalized

traditional

calligraphy,

pictographic

calligraphy, new

calligraphic art)

\section{Gordon Barrass:}

4 currents

(classicism,

modernism.

neoclassicism and

avant-garde)

[2002]

\section{[2001]}

Yang Yingshi:
3 approches (innovation,
subversion, and exploitation)
[2009]

Zhu Qingsheng

3 tendencies (art of

Chinese characters,

conceptual art, third

abstraction) [2011]

Figure 3. A schematic model of the main hypothesis of classification of the artistic production of the so-called "Chinese modern calligraphy" arranged by the author. The 24 different hypothesis have been grouped into two categories, the first 21 written in Chinese language (on the left, in orange) and the second six written in Western language (on the right, in light blue). The boxes colored in light orange contain classifications proposed by Chinese scholars.

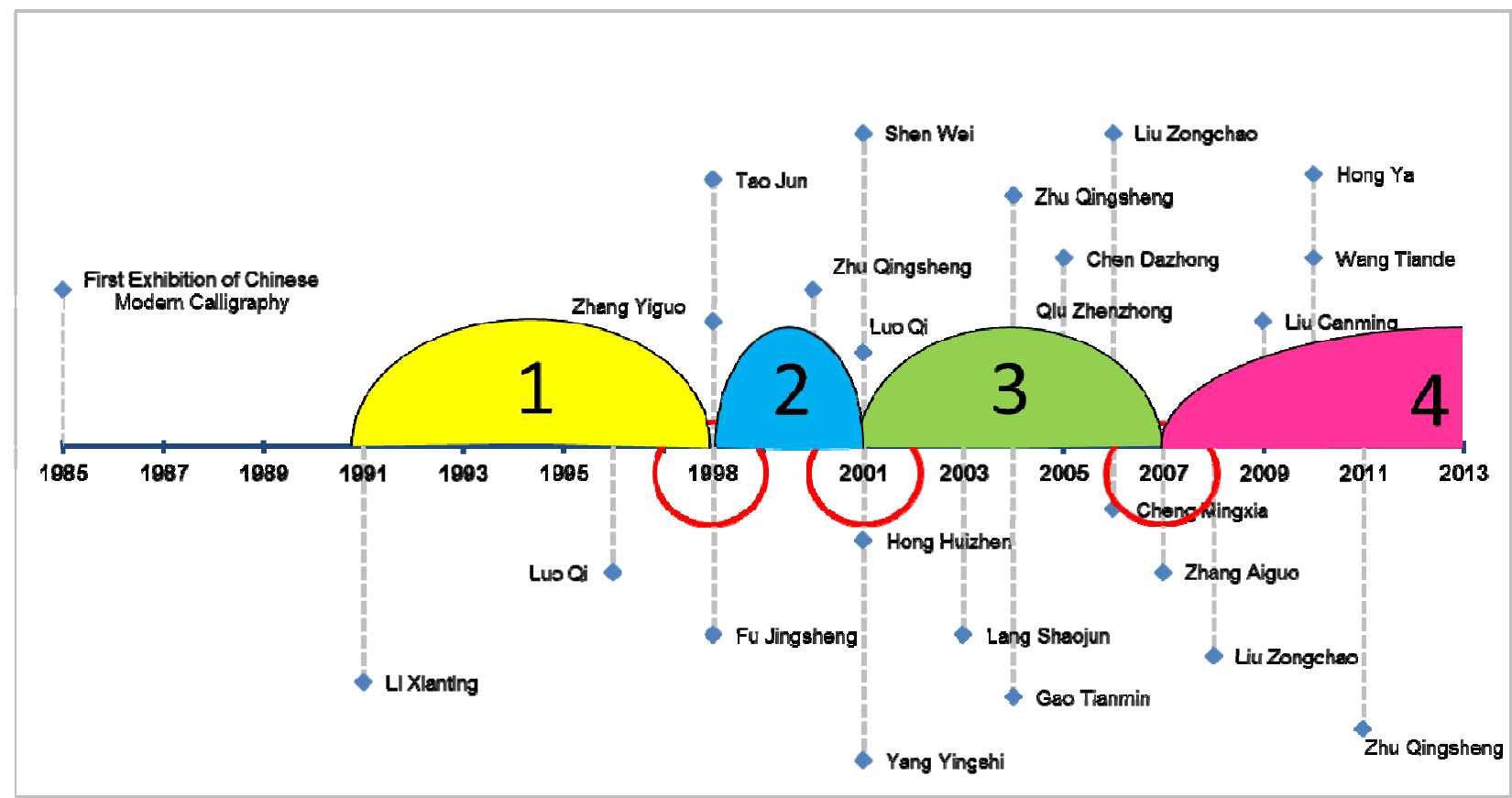

Figure 4. Timeline of the four main stages of the development of the critical debate on Chinese modern calligraphy arranged by the author. The dates in the red circles are the pivotal moments for the development of the discussion. 


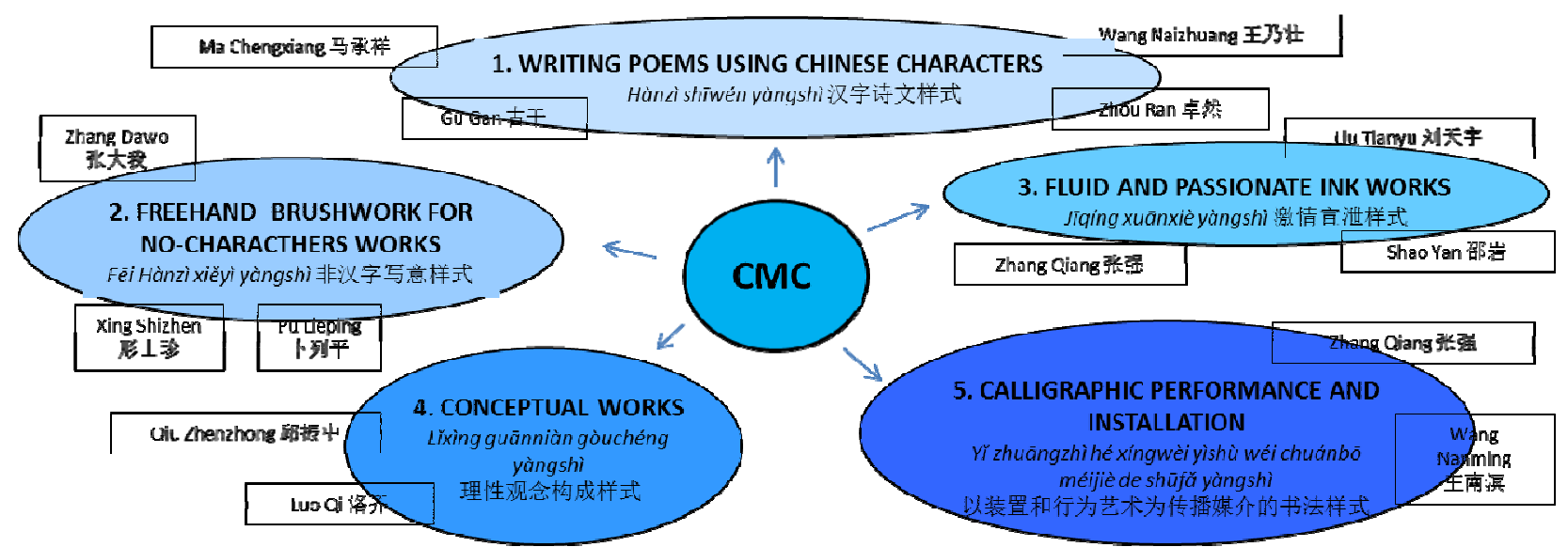

Figure 5. The classification of the Chinese modern calligraphy production into five typologies proposed by FU Qing-sheng and arranged by the author.

The other classifications emerged in this period focus only on extremely specific aspects. TAO Jun (1998), for example, only mentions the avant-garde movement, while ZHU Qing-sheng (2000) talks only about the artistic production of one artist in order to exemplify the major currents of the CMC. A common feature of all these classifications is the reference to a "traditional" calligraphic lexicon used to describe new forms of modern calligraphy.

(3) The third stage, from 2001 to 2006, is characterized by an "internalization" of the calligraphic lexicon used by Chinese scholars, in fact: (1) For the first time, Chinese art critics begin to speak about the interaction between calligraphy and contemporary art (LUO, 2001; YANG, 2001; ZHU, 2004); (2) the artists and the artworks analyzed increase and also foreigner artists begin to be named; (3) starting from the FU Qing-sheng classification, that represents the model in this period, two more typologies nearer to the global comprehension are added: These two typologies are "calligraphic abstraction" and "calligraphic collage"; (4) the word "anti-calligraphy" is replaced with the term "deconstruction of calligraphy", more suitable for contemporary lexicon; (5) artists and artworks are not only named (as it was before) but sometimes also analyzed (SHEN, 2001; LUO, 2001, etc.); (6) the approach is more scientific and, even if the reference to calligraphy is still the core of the classifications, it is not the only one; (7) for the first time "calligraphy" begins to be considered only as a "resource" or the "starting point" of the creative process (SHEN, 2001; HONG, 2001; YANG, 2001; LANG, 2003; QIU, 2004).

(4) The fourth stage, from 2007 until now, which is characterized by three main approaches to arrange this complex matter, really represents a synthesis of the previous three stages: Classifications become part of the first four Ph.D. thesis written on this topic (the first one is by ZHANG Ai-guo in 2007; then LIU Zong-chao in 2008, LIU Can-ming in 2009, and WANG Tian-de in 2010). Even if the authors try to have a scientific approach to the question, and each of them adopts different perspectives, sometimes there is a problem regarding a lack of objectivity. LIU Zong-chao has a "traditional" approach: he focuses in particular on the transformations of "traditional" calligraphy and it refers quite almost only to Chinese academic circles. ZHANG Ai-guo focuses on the concept of Hàn zì "Chinese characters": The first four categories of his classification refers to this keyword, while the other ones are arranged on the base of questionable criterions (just consider that the last one is created only to contain his own works). LIU Can-ming revises and reformulates ZHANG Ai-guo's perspective, focusing on the manipulation of Chinese characters. Except for the 
last proposal by WANG Tian-de, who uses the concept of "ink art" to propose new tendencies of CMC, we pass from an attempt to "internationalize" a "local" matter/lexicon in the previous period (2001-2006) to a reassertion of Chinese artistic lexicon by means of a traditional approach (see LIU Zong-chao), or using Chinese elements like Hànzì (see ZHANG Ai-guo and LIU Can-ming).

The author thinks that the difference among these approaches depends in particular on the "artistic identity" of the four scholars: The first one is a traditional calligrapher, the second and the third are modern calligraphers, and the fourth is an artist that sometimes uses calligraphy in his works.

The identity of the scholars is in fact one of the most important elements to understand the way they classified the artistic production of the so-called CMC. As you can see in the chart below (see Figure 6): (1) Most of the scholars interested in CMC are also calligraphers (12 out of 17), (2) most of them are calligraphers involved in the modern movement (8 out of 12); (3) and in their analysis all of them tend to point out the relevance of their artistic circle and include their own names and artworks in classification. The result is obviously a lack of objectivity; (4) then, just because in their being calligraphers they are still deeply rooted in traditional aesthetics, in their essays they continue to use a calligraphic lexicon, which is obviously comprehensible only inside their circles. It's not a case that the only four scholars who try to propose new visions are "pure" art critics (LI Xian-ting and YANG Ying-shi) or calligraphers who are also painters, or better who are more painters than calligraphers (LUO Qi and WANG Tian-de); (5) all of them also belong to Chinese academic institutions, sponsored by the government, so, like the ancient literati in the Imperial China, they formed hermetically closed circles, difficult to understand outside China and so not open to a global comprehension.

\begin{tabular}{|c|c|c|c|c|c|}
\hline ART CRITIC & CALLIGRAPHER & MODERN CALLIGRAPHER & INCLUSION IN CLASSIFICATION & CALLIGRAPHICLEXICON & ACADEMIC \\
\hline Zhu Qingsheng & YES & $x$ & $x$ & YES & $\mathrm{x}$ \\
\hline Shen Wei & YES & $x$ & $x$ & YES & $\mathrm{x}$ \\
\hline Luo Qi & YES & $x$ & $\mathrm{x}$ & NO ("cal igraphism") & $x$ \\
\hline Qiu Zhenzhong & YES & $x$ & $x$ & YES & $x$ \\
\hline Zhang Aiguo & YES & $x$ & $x$ & YES (HOnzi) & $x$ \\
\hline Liu Canming & YES & $x$ & $x$ & YES (Hanzl) & $x$ \\
\hline Wang Tiande & YES & $x$ & $\mathrm{x}$ & NO(ink painting) & $x$ \\
\hline Chen Dazhong & YES & $x$ & & No & $x$ \\
\hline Hong Huizhen & YES & & & NO:"-ism") & $\mathrm{x}$ \\
\hline Tao Jun & YES & & & YES (Hanzi) & $x$ \\
\hline Lang Shaojun & YES & & & YES & $\mathrm{x}$ \\
\hline Liu Zongchao & YES & & & YES (tradition VS moderrity) & $x$ \\
\hline Zhang Yiguo & NO & & & YES (tradition VS moderrity) & $x$ \\
\hline Gao Tianmin & No & & & YES & $\mathrm{x}$ \\
\hline Fu Jingsheng & NO & & & YES & $x$ \\
\hline Yang Yingshi & NO & & & NO & $x$ \\
\hline Li Xianting & NO & & & NO (calligraphy VS painting) & \\
\hline
\end{tabular}

Figure 6. Table of the main Chinese art critics interested in Chinese modern calligraphy arranged by the author. This table shows if these art critics are also calligraphers (second column), modern calligrapher (third column), academic (sixth column), if they include their own names in classifications (forth column), and which kind of artistic lexicon they used in their classifications (fifth column). 
The inadequacy and limits of this kind of perspective, especially for an international audience, is so evident. It is just starting from this assumption and after analyzing more than 200 artists involved in the calligraphic modern movement, that the author finally proposes a new classification of the so-called CMC: Two are the main currents (Barrass, 2002): the modernists and the avant-garde. The first one focuses on stylistic exploration of calligraphic art, and it is characterized by three different tendencies: (1) pictorial-pictographic tendency; (2) toward abstraction and new spatial compositions; and (3) calligraphic collage. The second one aims at a radical and total transformation of calligraphic art: The Chinese characters are no longer recognizable because of the "deconstruction of calligraphy" (conceptual current) or because the focus is on the abstract beauty of calligraphic line (abstract currents) or instead because the medium has been changed (from the "four treasure of the study" to performance, dance, multimedia art, and graffiti art). ${ }^{7}$

\section{Conclusion}

As it has been illustrated in this article, the critical debate on modern calligraphy in contemporary China focuses on three main questions: (1) definition of the phenomenon; (2) analysis of its nature; and (3) classification of the artistic production. From the end of the nineties, Chinese art critics try to solve these debated questions suggesting most of different names, categorizations, and codifications, but none of them seems to provide a joint and unanimous solution. According to the author, the only thing to do is not to give a fixed label to a changeable phenomenon like that of the so-called "CMC" (as most of the Chinese scholars have done), but to focus on the concept of "modernity" in Chinese calligraphy. Then, just because of its Janus nature, we do not have to think of it as a unitary phenomenon, but we have to distinguish two different faces of the same phenomenon: WANG Dong-ling's and WANG Nan-ming's perspectives. Finally, considering the inadequacy and "scientific" limits of the Chinese attempts to classify the artistic production, we have to think of a new proper classification, which must be comprehensible also outside China, and suitable for a global contest. All of this in order to give a general, comprehensive view of the present theoretical discussion on a complex and multifaceted phenomenon is considered the calligraphy metamorphosis in China nowadays.

\section{References}

Barrass, G. (2002). The art of calligraphy in modern China. London: British Museum Press.

CHEN, D. Z. (2005). 当代书法创作模式与派流研究 (Dangdai shufa chuangzuo moshi yu pailiu yanjiu). Beijing: Rongbaozhai Press.

CHEN, E. C. (2010). "Harmonious and Integrated Culture” and the Building and Communication of China's National Image, Intercultural Communication Studies. Retrieved from http://www.uri.edu/iaics/content/2010v19n1/11ErchunChen.pdf

CHEN, Z. L. (1996). 现代中国书法史 (The history of modern Chinese calligraphy). Zhengzhou: Henan meishu chubanshe.

CHENG, M. X. (2006). 现代书法”创作思维模式初探 (Xiandai shufa” chuangzuo siwei moshi chutan). In B. Wen, \& J. C. SU (Eds.), 中国现代书法20年学术研究会论文集 (Zhongguo xiandai shufa 20 nian xueshu yanjiuhui lunwenji). Hong Kong: Hong Kong Oriental Art Centre.

Chew, K. L. (2001). Transcending limits: A centenary journey from traditional Chinese calligraphy to new art calligraphic art. Retrieved from http://www.niubizi.com/02_wenzihua/ 02b3_chew.html

FU，J. S. (1998). 中国现代书法的类型及其它 (Zhongguo xiandai shufa de leixing ji qiwen). Retrieved from http://wuxizazhi.cnki.net/Search/MSGC199806004.html

FU, J. S. (2001). 傅京生书法论集 (Fu Jingsheng shufa lunji). Beijing: Culture and Art Press.

\footnotetext{
${ }^{7}$ For a more detailed analysis of the Avant-garde currents, see Iezzi, A. (2013), “Contemporary Chinese Calligraphy between tradition and innovation” (pp. 167-176).
} 
FU, J. S. (2011). 中国现代书象 (The shape of Chinese modern calligraphy). Beijing: Culture and Art Press.

GAO, T. M. (2004). “现代书法”的含义 (“Xiandai shufa” de hanyi). In D. L. WANG (Ed.), 中国“现代书法”论文选 (Florilegium of theses on contemporary Chinese calligraphy). Beijing: China Fine Arts Press.

GU, G. (1992). 现代书法漫议 (Xiandai shufa manyi). Retrieved from http://wuxizazhi.cnki.net/Search/MUSE199204007.html

HONG, H. Z. (2001). 书法资源的现代开发与利用 (Shufa ziyuan de xiandai kaifang yu liyong). In Q. LUO (Ed.), Shufa yu dangdai yishu (Calligrafia e arte contemporanea). Hangzhou: China Academy of Art Press.

HONG, Y. (2010). 审美现代性理论关照的 “现代书法” (A study of “modern calligraphy” from the perspective of theories of aesthetic modernity) (Ph.D. thesis, Hangzhou: China Academy of Art).

HUANG, Z. Y. (2011). 伏流.扬波一战后至今(1945-2010)台湾现代书法发展研究 (Fuliu yangbo一Zhanhou zhijin (1945-2010) Taiwan xiandaishufa fazhan yanjiu) (Ph.D. thesis, Hangzhou: China Academy of Art).

Iezzi, A. (2013). Contemporary Chinese calligraphy between tradition and innovation. Journal of Literature and Art Studies, 3(3), 158-179.

LANG, S. J. (2003). 序言 ・书法的“现代化’一关于‘书法主义’的答问 (Xuyan Shufa de “Xiandaihua”-Guanyu “shufazhuyi” de dawen). In Y. ZHANG \& M. SHEN (Eds.), 书法主义 (Shu fa zhu yi). Changsha: Hunan Fine Arts Press.

LI, X. T. (1991). “现代书法”质疑一从“书法同源”到“书画归一” (“Xiandai shufa” zhiyi一Cong “Shuhua tongyuan” dao "Shuhua guiyi”). Retrieved from http://www.shufawu.com/portal.php?mod=view\&aid=3731

LI, Y., \& LIU, Z. C. (2009). 新中国书法60年: 1949/2009 (Calligraphy 60 Years in China: 1949-2009). Shijiazhuang: Hebei meishu chubanshe.

LIU, C. M. (2010). 中国现代书法史 (The history of modern Chinese calligraphy). Nanjing: Nanjing University Press.

LIU, K. H. (2008). 20世纪末期中国现代书法的创作情境 (The situation of modern Chinese calligraphy at the end of the 20th century). Retrieved from http://wuxizazhi.cnki.net/Search/YSBJ2008S1097.html

LIU, Z. C. (2006). 试析当代书法创变模式(上、下) (Shixi dangdai shufa chuangbian moshi (shang, xia)). Retrieved from http://www.zgyb.org/lilun/liuzongchao007.htm

LIU, Z. C. (2008). 中国书法现代创变理论之反思 (Zhongguo shufa xiandai chuangbian lilun zhi fansi). Nanchang: Jiangxi Fine Arts Press.

LU, D. D. (2004). Zhongguo xiandai shufa dashi nianbiao (中国现代书法大事年表). In D. L. WANG (Ed.), 中国“现代书法”论 文选 (Florilegium of theses on contemporary Chinese calligraphy). Beijing: China Fine Arts Press.

LU, F. S. (2004). “现代”之前的徘徊 (“Xiandai” zhi qian de paihuai). In D. L. WANG (Ed.), 中国“现代书法”论文选 (Florilegium of theses on contemporary Chinese calligraphy). Beijing: China Fine Arts Press.

LUO, Q. (1993). 书法主义宣言(Shufazhuyi xuanyan). In D. L. WANG (Ed.), Zhongguo 'Xiandaishufa' lunwen xuan 中国“现 代书法”论文选 (Florilegium of theses on contemporary Chinese calligraphy). Beijing: China Fine Arts Press.

LUO, Q. (2001). Shufa zhong de dangdai yishu yu dangdai yishu zhong de shufa (书法中的当代艺术与当代艺术中的书法). In Q. LUO (Ed.), Shufa yu dangdai yishu (书法与当代艺术). Hangzhou: China Academy of Art Press.

MA, Q. Z. (2004). 先锋书法的现代情境 (Xianfeng shufa de xiandai qingjing). In D. L. WANG (Ed.), 中国“现代书法”论文 选 (Florilegium of theses on contemporary Chinese calligraphy). Beijing: China Fine Arts Press.

PU, L. P., \& GUO, Y. P. (2005). 中国现代书法到汉字艺术简史 (Zhongguo xiandai shufa dao hanzi yishu jianshi). Chengdu: Sichuan Fine Arts Press.

QIAN, Q. G. (2002). 中国现代书法创新之我见 (Zhongguo Xiandai Shufa chuanxin zhi wo jian). Retrieved from http://mall.cnki.net/magazine/Article/NJYS200002010.htm

QIU, Z. Z. (2004). Yuanzi shufa一Dui yilei yishu de mingming yu qita 源自书法一对一类艺术的命名与其他. Xiandaishufayanjiubao, 4.

QU, L. F. (2008). 重估20世纪末中国“现代书法运动” (A revaluation of modern Chinese calligraphy in the late 20th century). Retrieved from http://www.cssn.cn/st/st_wybht/201403/t20140306_1021566.shtml

SHEN, W. (2001). 中国当代书法思潮一从现代书法到书法主义(Zhongguo dangdai shufa sichao-Cong xiandai shufa dao shufazhuyi). Hangzhou: China Academy of Art Press. 
TAO, J. (1998). “飞 地”书法点 评 (“Feidi” shufa dianping). Retrieved from http://www.cnki.com.cn/Article/CJFDTOTAL-MSGC199806018.htm

WANG, D. L. (2005). 享受现代书法的智慧 (Enjoy the wisdom of modern calligraphy), Art China, 4(3), 6-11.

WANG, D. L. (2010). 王冬龄谈现代书法 (Wang Dongling tan xiandai shufa). Beijing: Renmin University Press.

WANG, N. M. (1994). 理解现代书法: 书法向现代和前卫的艺术转型 (Understanding modern calligraphy). Nanjing: Jiangsu Educational Press.

WANG, N. M. (2005). 后抽象艺术与观念艺术中的书法“暗示” (Calligraphic hints in post-abstract art and conceptual art). Art China, 4( 3), 12-14.

WANG, T. D. (2010). 现代书法的水墨形态 (Xiandai shufa de shuimo xingtai) (Ph.D. thesis, Hangzhou: China Academy of Art).

WANG, X. Z. (1986). 现代书画学会书法首届作品选 (Xiandai shuhua xuehui shufa shoujie zuopin xuan). Beijing: Beijing Sport University Press.

Wear, E. (2008). Square words, round paradigms: Contemporary calligraphy in China. Retrieved from http://artasiapacific.com/Magazine/58/SquareWordsRoundParadigmsContemporaryCalligraphyInChina

XU, P. Z. (2010). Cong yizhi dao zhagen—Xianggang xiandai shufa shi yanjiu (1945-2010) 从移植到扎根一香港现代书法史 研究(1945-2010) (Ph.D. thesis, Hangzhou: China Academy of Art).

YANG, Y. S. (2000). Cronology of Chinese modern calligraphy (1985-1999). Retrieved from http://www.china-gallery.com/en

YANG，Y. S. (2001). 书法作为资源: 中国当代艺术的新方向 (Shufa zuowei ziyuan: Zhongguo dangdai yishu de xinfangxiang). In D. L. Wang (Ed.), 中国“现代书法”论文选 (Florilegium of theses on contemporary Chinese calligraphy). Beijing: China Fine Arts Press.

YANG, Y. S. (2009). La Calligraphie et le concept: Le nouveaux courants contemporains (Calligraphy and concept: The new contemporary currents). In D. A. Fan \& Q. S. Zhu (Eds.), Le Pavillion des Orchidées. L'art de l'écriture en Chine. Bruxelles: Fonds Mercator.

ZHANG, A. G. (2007). 中国“现代书法”蓝皮书 (The Blue Book of the Chinese “Modern Calligraphy”). Hangzhou: China Academy of Art Press.

ZHANG, N. (1999). A criticismof the complex of modern calligraphy at the end of the century. In Y. S. YANG (Ed.), Bashu Parade: 99 Chengdu Retrospective of Chinese Modern Calligraphy at the End of the Twentieth Century. Chengdu: Sichuan International Cultural Exchange Center.

ZHANG, Q. (1993). 现代书法学综论 (A comprehensive review of modern calligraphy). Jinan: Shandong youyi shushe.

ZHANG, Y. G. (1998). Brushed voices: Calligraphy in contemporary China. New York: Columbia University Press.

ZHU, Q. S. (2000). 从无锡到北大一我所经历的现代书法试验 (Cong Wuxi dao Beida: Wo suo jingli de xiandai shufa shiyan). Retrieved from http://www.docin.com/p-235766524.html

ZHU, Q. S. (2004). 中国现代书法的层次与方向 (Zhongguo xiandai shufa de cengci yu fangxiang). In D. L. WANG (Ed.), 中 国“现代书法”论文选 (Florilegium of Theses on Contemporary Chinese Calligraphy). Beijing: China Fine Arts Press.

ZHU, Q. S. (2009). Ink painting, calligraphy and the third abstraction. Retrieved from http://www.artzinechina.com/display_vol_aid814_en.html

ZHU, Y. S. (2004). “Houxiandai shufa” shenmei lüelun “后现代书法”审美略论. In D. L. WANG (Ed.), 中国“现代书法”论文 选 (Florilegium of Theses on Contemporary Chinese Calligraphy). Beijing: China Fine Arts Press. 